\title{
The Neo-Patrimonial 'Use' of Drug Policy in Electoral Processes
}

\author{
Khalid Tinasti
}

\begin{abstract}
The prohibition of illegal drug production, use and trafficking has resulted in several shortcomings and negative consequences for other global development objectives. According to available evidence, current drug control policies undermine the international community's commitments to public health, criminal justice, sustainable development, women rights, human rights, poverty alleviation and the reduction of inequalities. This policy comment focuses on the impact of repressive drug policies on state institutions and politics.

In a unique conjunction of interests, prohibition allows transnational criminal organisations to weaken state institutions, corrupt civil and military officials and influence control policies because of the entrenched neo-patrimonialism in political life. Therefore, prohibition allows populist and political contenders to stigmatise a minority population-people who use drugs, in opposition to the desires of the majority rule. The use of political emotions, based on fear or promise of change, undermines effective responses to drugs, erodes the rule of law and trust between authorities and populations, and weakens state institutions and democratic governance. This policy comment provides examples from low- and middle-income countries, as well as cases from high-income countries, of the impact of drug prohibition and its illegal proceeds on governance through neo-patrimonialism, clientelism and the weakening of institutions.
\end{abstract}

\section{Introduction}

The international drug control regime, defined by international drug conventions (the Single Convention on Narcotic Drugs of 1961 as amended by the 1972 Protocol, the Convention on Psychotropic Substances of 1971, and the United Nations Convention against Illicit Traffic in Narcotic Drugs and Psychotropic Substances of 1988), has as its main objective the elimination or significant reduction of the production, recreational use and trafficking of illegal drugs. These 
conventions allow access to drugs for medical use or scientific research. They set the parameters for reducing the demand and supply of drugs, for cooperating judicially, and for eliminating drug money laundering (UNODC, 2013). Moreover, they contain the schedules of drugs - the tables that define which drugs are illegal and which are to be controlled - as well as what level of control is to be imposed on access to these substances.

There is extensive literature and evidence of the failure of the current control regime, based on prohibition and repression, to achieve any of its objectives in eliminating recreational drug use (GCDP, 2011; Csete et al., 2016). Furthermore, compliance with laws and policies prohibiting the use of drugs is weak, proven by the fact that several hundreds of millions of people use drugs annually.

The international control regime inspired national laws and coincided with national and regional escalations against illegal drugs. The most famous was United States (US) President Nixon's 'war on drugs' in 1971 (Nadelmann, 1998). Repression and law enforcement were used to counter the production of coca in the Andean region, opium in the Golden Crescent and the Golden Triangle and cannabis on a global scale. At the same time, national political frameworks, especially in countries that were under colonial rule in the first half of the twentieth century, have seen the development of neo-patrimonial regimes based on single parties, on military rule, or on authoritarian rule, and where social peace was usually 'bought' by the leaders in place in a client-patron relationship with their constituencies.

The sheer extent of the demand for drugs, as well as the value of the illegal market and its control by criminal organisations, provides illicit resources so extensive that they have the power to cripple state institutions, corrupt officials and deepen the neo-patrimonial nature of many political systems, as well as undermine the rule of law by expanding defiance between authorities and populations (GCDP, 2014). Current drug policies based on prohibition and repression, combined with weak institutional frameworks and allowance bases in several political systems, have a deep impact that can be seen in places such as Latin America, where corruption reaches high levels (Morris, 2012), Africa, where fragile institutional frameworks and presidentialism offer fertile ground for illicit funds (WACD, 2014), and high-income countries in specific marginalised and poor areas, where local or national Big Men ${ }^{1}$ hold political power

1 Big Men as a political science concept was developed by Jean-François Médard (1990), and inspired by the work of the anthropologist Marshall Sahlins on Melanesian Big Men, as socially important individuals that carry a mix of interest to the general well-being and calculations for personal interests, men that want the central place in society, and whose every 
based on clientelism. The availability of drug proceeds has, on the one hand, allowed organised crime to infiltrate state institutions. On the other, it has blurred the lines between the officials' role as those in charge of ending drug trafficking, and the fact that those same officials ultimately benefit from it.

The use of drugs has been steadily increasing, as documented over the past twenty years, and so has the illegal market (IDPC, 2018). The supply chain tends to find different ways of adapting to prohibition in order to respond to this existing demand - which has been described by many scholars and governments as the 'unintended' consequence of drug control-resulting in the empowerment of criminal organisations and providing them with the capacity to weaken state institutions and smuggle drugs, corrupt officials, and influence the control measures put in place in different jurisdictions. This policy comment goes further, by highlighting the opportunistic links between drug trafficking, criminal activity, political funding and electoral cycles. They each feed each other, support each other when needed, and fiercely fight each other when it best serves their interests.

The nature of political authority and its relationship to public institutions in dominantly drug producing and transit countries differ from those in dominantly consuming countries. The majority of the former were achieving independence and establishing their state institutions and political systems at the time of the adoption of the international drug control regime, starting with the Single Convention on Narcotic Drugs in 1961. The drug control regime, based on prohibition, can thus be seen as antithetical to the nature of institutions in these countries, where both formal and informal institutions influence the political system. One of the main characteristics of these informal institutions is neo-patrimonialism. The term is derived from the concept of patrimonialism, which Max Weber uses to describe the principle of authority in traditional politics (Weber, 2003 [1921]). ${ }^{2}$ The neo-patrimonial concept,

action calls for confrontation with others to prove the superiority that they themselves stage. For Médard, the Big Man must create loyalty with as many people as possible for his benefit, so that he can then mobilise his clients to gain prestige compared to his political competitors.

2 In patrimonial political systems, an individual holds the power and exercises it for his personal prestige, giving the people only limited rights. Authority is fully personalised, more shaped by the leader's preferences than by a codified system of laws. The leader ensures political stability and his own political survival by providing a safe zone in an uncertain 
developed by Jean-François Médard, takes the following meaning: 'the notion of neo-patrimonialism has for us the interest of being less normative than that of corruption and more comparative than that of the "politics of the belly" '3 (Médard, 1990).

The neo-patrimonial nature of these regimes during their establishment has allowed for political funding vacuums, where the proceeds of drug trafficking - for example, with fragile economies, nascent state institutions, and in the middle of the Cold War-became important sources of revenue for the consolidation of the political regimes themselves. In the case of Mexico, it is reported that the Partido Revolucionario Institucional (PRI, the former unique party and ruling party since 1929 with alternation for two mandates in 2006 and 2018) built relationships with drug trafficking to fund political campaigns (Andrés and Delia, 2017). In the case of West Africa, these informal neo-patrimonial characteristics are based on several rents from what were illicit economies at independence, including the control by the state of formerly illegal markets for diamonds, precious metals, oil, or fishing; and current illicit economies such as the increase in drug trafficking are fuelling corruption and funding political campaigns (FelbabBrown, 2010).

Another characteristic of informal economies with an impact on democratisation and politics in these countries is the use of drug control to consolidate political power, and that could be read through the lenses of presidentialism and the role of Big Men. In contemporary politics, such a situation can be found in the Philippines, where-during the presidential campaign in 2016the Duterte Administration condoned drug killings and promised to eradicate drugs (IDPC, 2018). More recently, the Hasina Administration condoned extrajudicial arrests of political opponents on drug-related offences ahead of the 2018 general election in Bangladesh (The Daily Star, 2019). This characterisation of the Big Man resorting to drug policy to affirm his political credentials can also be seen in the US, where the Trump Administration simplifies complex drug markets and the interconnectedness of trafficking, money laundering, production and ethnic networks in the Americas into blame for migrants and the Mexican authorities (Klar, 2019). Such a discourse is constructed for the sole benefit of the political leader, and not to reduce drug trafficking, use,

environment, and redistributing the wealth to the populations, who are no longer citizens but become customers in a clientelist relationship.

3 Translated by the author, original text in French: « La notion de néo-patrimonialisme a pour nous l'intérêt d'être moins normative que celle de corruption et plus comparative que celle de 'politique du ventre' » (Médard, 1990, 29). 
or production, or to protect the well-being of the communities concerned by the negative consequences of drug policies.

\section{Drug Trafficking and Neo-Patrimonialism in State Institutions}

State institutions, in adopting the prohibition of drugs in the 193os and reconfirming this position in the 196os, have given up control of the drugs issue, inadvertently or not, placing organised crime as the central authority for market regulation, while retaining the role of mitigating harmful effects (Tinasti, 2019). This policy choice of prohibition cannot be effective without the elimination of the demand and the supply of illegal drugs, and can only therefore strengthen the financial and structural capacity of transnational criminal organisations.

Two of the unintended consequences of the international drug control regime, as defined by the United Nations (UN) and based on 'reactive law enforcement' activity (UNODC, 2008), are directly linked to the weakening of state institutions: policy displacement and geographic displacement.

The former is highlighted by state investments in drug law enforcement, estimated at USD 100 billion annually (Transform Drug Policy Foundation, no date). According to UN estimates, an annual investment of USD 1.15 billion would cover the needs of all people who inject drugs (PWID) globally and end HIV transmission among this population through investments in health and harm reduction services (Schwartlender et al, 2011). Such disproportionate budget allocation, which clearly ignores the fact that public health should be the first priority in terms of drug control, reinforces the negative impact of drug control policies not only on people who use drugs and on their communities, but also on society. This example also links to the preference of political regimes to use 'tough stance on crime' approaches and provide more resources to law enforcement agencies than to health agencies, without specific evaluations of the outcomes of such a policy preference.

Geographic displacement, also known as the 'balloon effect', refers to the relocation of the market from one location, where control measures are tight, to another, where controls are more lenient. In history, successes in controlling illegal cocaine production in Peru led to the displacement of production and its related problems to neighbouring Colombia and Bolivia. Moreover, in recent decades, the balloon effect saw the traditional cocaine trafficking route in Central America and the Caribbean migrate towards a route from Latin America to Europe and North America, crossing the Atlantic twice and transiting through West African countries. 
This new route uses similar methods to smuggle drugs through West Africa. It relies on weak institutions in the region, it highlighted corruption of highlevel officials, both civilian and military, and the neo-patrimonial nature of political regimes, and it weakened the rule of law (WACD, 2014). A lack of accountability structures, combined with weak law enforcement and ineffective financial system regulations to counter money laundering, along with the insufficient capacity of the judicial system, combined with normalised clientelist political behaviour, means countries in the region are more vulnerable to the reach and power of transnational organised crime (Olukoshi, 2013).

The African routes (cocaine through West Africa and heroin through the eastern coast of Africa) are representative of geographical displacement and its impact on governance and state institutions. The choice to strategically smuggle the substances along these routes is not only based on ethnic relationships that facilitate illegal trade (West African networks in Western Europe; Asian families' networks in East Africa) or on the strategic geographic position of the continent. It also depends on multilayered gaps in governance, weak institutions, and how easy these make it to infiltrate the legal economy and corrupt officials that are already basing their political legitimacy on clientelism and allowances granted. This situation is exacerbated by money laundering in highincome countries. For instance, 99 per cent of the illicit financial flows from drug proceeds laundered in Europe, where financial regulations seem stricter than elsewhere, are not recovered (Europol, 2017). According to the UN, half of the estimated profits of the illegal drug market are laundered through the legal financial system, and confiscations remain limited (UNODC, 2017).

Finally, the examples provided also highlight the vicious cycle of neopatrimonialism leading to corruption, itself feeding weak institutions and illicit financial flows. Weak institutions-especially in areas of conflict or countries experiencing socio-economic difficulties-represent, in return, fertile ground for criminal organisations. Once these organisations infiltrate such environments, they become sources of ineffective institutions and political, social, and economic instability, ultimately influencing policy outcomes. The seemingly endless cycle destabilises any efforts to implement sustainable development.

With the same combination of policy gaps, poor areas in Mali saw the development of the illegal market as a substitute for the welfare state, providing basic services and employment opportunities to local communities. This results in the weakening of the rule of law and state interventions, and destabilises the relationship between communities and state institutions (GCDP, 2018). On the other side of the continent, powerful drug trafficking families are linked with the political elite from the ruling party in Mozambique, highlighting 
corruption-from the top levels of state government to the smallest police units in border areas of the country. Moreover, these few families have succeeded in ensuring their legal protection through corruption using illicit drug proceeds (Haysom et al., 2018).

Drug trafficking proceeds are also used to undermine electoral processes, to weaken political competition by intimidating certain candidates or supporting others, and to define political participation by influencing a population's choices and the ability to vote freely. For example, the assassinations of the front runner in the Colombian presidential campaign of 1990 by cartel members or of more than a hundred politicians by criminal organisations between 2017 and 2018 in Mexico showcase the power of organised crime in impacting democratic processes, including by the use of violence (Agren, 2018).

Drug control policy is also used to influence voters' choices even in established democracies. In France, Nicolas Sarkozy (President, 2007-12) used drug policy in his presidential campaigns of 2007 and 2012 to take a 'tough stance on crime', and to focus law enforcement efforts on the banlieues-French social housing-dominated suburban areas with major socio-economic challenges, the majority home to ethnic minorities (Gross, 2012). Taking an opposite approach, Canada's Justin Trudeau (Prime Minister, 2015-present) included the legalisation of cannabis on his electoral platform in 2015 , based on the commitment to address the problematic use of cannabis, especially among minors, and to take the market away from criminal organisations that decide on the potency and availability of the substances they sell.

Whether they provoke fear or promise reform, these examples demonstrate a clear link with political emotions (Stoler, 2018). They trigger support for or rejection of an electoral platform, a party, or a candidate. Prohibitionist discourses play on the fear of insecurity related to the violence generated by the illegal market, the anger of citizens at state institutions' failure to provide safe and inclusive cities, and the hope that a harsher response to drugs will ultimately eliminate the drug market.

Moreover, the use of drug control policies to influence electoral processes is more visible, as it coincides with two major milestones that changed the reception of political discourses: the general 'democratic recession' of the last decade and the progress of drug policy reform movements. The democratic recession can manifest itself in restrictions of personal freedoms, the breakdown 
of democratic practices, the instability of democratic institutions, or the rise of authoritarianism (Diamond, 2015). The instability and illiberal nature of third wave democracies (Huntington, 1991) tended to see electoral competitors rely on and be inspired by the 'war on drugs' rhetoric to advance their own political agendas, or to conceal their own shortcomings.

In the Philippines, for instance, drugs have become an important health and social issue due to a concentration of contemporary social, political, environmental and economic challenges. Drugs did not, however, cause these problems, as the Philippine administration claims. With a steady increase in economic inequalities, the lack of a welfare state, climate catastrophes, an exploding demography, religious and ethnic conflicts, and a high prevalence of drug use, drug policies based on repression were an aggravating factor of a generalised societal 'ill-being', rather than its cause. Furthermore, after three years of state-condoned extrajudicial killings, the prevalence of use or trafficking of drugs does not show any signs of receding, even if the government claims a reduction in crime of 30 per cent.

It should be noted that this figure should be understood in the context of an illegal market that continues to flourish, but functions under more difficult constraints, thereby exposing vulnerable and impoverished communities to more violence. Moreover, the targeted use of the 'war on drugs', which increased during the midterm elections in May 2019, has established a culture of political violence in the country (Kishi and Raleigh, 2019). This data does not, however, undermine administrations' populist approach of using the 'war on drugs' for political gain, since taking a 'tough stance on crime' in times of crisis is attractive to the voting body (Kenny, 2019). This trend of majoritarianism is visible even in established democracies, where increasing portions of the electoral body cast their votes in favour of populist movements.

Transnational criminal organisations also use their financial and social power to influence the outcomes of electoral processes or to weaken state institutions at different levels of the supply chain (UNODC, 2017). On the funding of electoral campaigns, Guinea-Bissau remains the most documented example. Anecdotal data on the funding of elections and support from organised crime and drug proceeds can, however, also be found in Mauritania, Jamaica, Ghana and Sierra Leone during the last two decades (Gberie, 2013). Corruption incentives from criminal organisations also influence the military. Examples include weapons reportedly transferred from the military to criminal organisations in Guatemala and almost 30 per cent of the military in Mexico deserting, often to engage in organised crime (Health Poverty Action, 2018). Another example is Indonesia, where corruption is so endemic in the police, corrections, and judicial systems that the US State Department has identified corruption 
as a barrier to reducing the supply of and demand for drugs in the country (Havenhand, 2019).

\section{$5 \quad$ Conclusions}

The analysis and country examples provided in this chapter highlight how the institutional capacity to trigger and sustain development, especially in lowand middle-income countries, is undermined by drug trade proceeds and the financial power of organised crime. Politics, political regimes, opposition rights, voter rights, and participation in public and political affairs are trumped by the prohibition paradigm, providing both criminal organisations and political hopefuls with opportunities to weaken democratic governance for their private gains. Prohibition has resulted in a grey area where the illegal drug market can be used to fund electoral cycles, but can also be used as an alibi as needed on political platforms and in political campaigns.

State institutions, by adopting the 'global prohibition' approach to drugs, have not only deprived themselves of the capacity to control the drug markets and handed, to some extent, enormous profits to criminals, they have also deprived themselves of their capacity to impose the rule of law and negatively impacted their relationships with their populations. The path that seems most appropriate to an effort to end this vicious cycle of neo-patrimonialism fed by corruption, illicit financial flows, and clientelism based on the proceeds of drug trafficking is the end of the prohibition of drug use. Legal regulation of all drugs, each by a different model according to its potential for harm and its uses, carries the promise of setting legal rules that apply to all. It could end the darkness and invisible yet defining spaces such as the illegal drugs market that allow for undemocratic governance, challenge the rights of political competition, favour those with access to illicit funds and networks, and hurt political participation by discriminating against certain targeted groups of citizens linked to the illegal drugs market, including harmless consumers.

\section{References}

Agren, D. (2018) 'Mexican candidate shot while posing for selfie in latest murder of politician', The Guardian, 12 June, https://www.theguardian.com/world/2018/ jun/12/mexico-election-politicians-killed-fernando-puron-selfie (accessed on 21 April 2020). 
Andrés, V.Z., and A.H. Delia (2017) 'Narco-Campaigns and Their Impact in the Electoral System and Government Regime: An Analysis of the Mexican Case', Journal of Political Sciences and Public Affairs, 5(3), pp.1-5.

Csete, J., A. Kamarulzaman, M. Kazatchkine, F. Altice, M. Balicki, J. Buxton, J. Cepeda, M. Comfort, E. Goosby, J. Goulão, C. Hart, R. Horton, T. Kerr, A. Madrazo Lajous, S. Lewis, N. Martin, D. Mejía, D. Mathiesson, I. Obot, A. Ogunrombi, S. Sherman, J. Stone, N. Vallath, P. Vickerman, T. Zábranský, and C. Beyrer (2016) 'Public health and international drug policy', The Lancet, 387(10026), pp. 1427-1480.

Diamond, L. (2015) 'Facing Up to the Democratic Recession', Journal of Democracy, 26(1), pp. 141-155.

Europol (2017) Serious and Organized Crime Threat Assessment 2017 (The Hague: Europol), https://www.europol.europa.eu/activities-services/main-reports/serious-andorganised-crime-threat-assessment (accessed on 21 April 2020).

Felbab-Brown, V. (2010) The West African Drug Trade in the Context of the Region's Illicit Economies and Poor Governance, Remarks presented at the October 14 Conference on Drug Trafficking in West Africa, in Arlington, Virginia (Washington D.C.: Brookings Institution).

Gberie, L. (2013) State Officials and their Involvement in Drug Trafficking in West Africa, WACD Background Papers 5 (Accra: West Africa Commission on Drugs), https:// www.globalcommissionondrugs.org/wp-content/uploads/2017/o2/State-Officialsand-Drug-Trafficking-2013-12-03.pdf (accessed on 21 April 2020).

GCDP (Global Commission on Drug Policy) (2018) Drug Policy and the Sustainable Development Agenda (Geneva: GCDP).

GCDP (2014) Taking Control: Pathways to Drug Policies That Work (Geneva: GCDP).

GCDP (2011) War on Drugs (Geneva: GCDP).

Gross, E. (2012) 'La banlieue bleue de Sarkozy', L'Obs, 16 March, https://www.nouvelobs. com/politique/election-presidentielle-2012/20120316.OBS3943/la-banlieue-bleuede-sarkozy.html (accessed on 21 April 2020).

Havenhand, G. (2019) Leave No One Behind: a Development-led approach to drug policy and criminal justice reform in Indonesia (London: Reprieve).

Haysom, S., P. Gastrow and M. Shaw (2018) The Heroin Coast: A political economy along the eastern African seaboard, ENACT working paper, https://globalinitiative.net/ wp-content/uploads/2018/o7/2018-o6-27-research-paper-heroin-coast-pdf.pdf (accessed on 21 April 2020).

Health Poverty Action (2018) 'The Development Impacts of the 'War on Drugs", in T. Reitano, L. Bird Ruiz-Benitez de Lugo and S. Jesperson (eds) Militarized Responses to Transnational Organized Crime: The war on crime (London: Palgrave).

Huntington, S.P. (1991) 'Democracy's Third Wave', Journal of Democracy, 2(2), pp. 12-34. IDPC (International Drug Policy Consortium) (2018) Taking stock: A decade of drug policy-A civil society shadow report (London: ID PC). 
Kenny, P.D. (2019) 'Populism and the War on Drugs in Southeast Asia', Brown Journal of World Affairs, 25(2), pp. 121-136.

Kishi, R. and C. Raleigh (2019) Midterm Elections in the Philippines: Power Consolidation at Its Finest, Armed Conflict Location \& Event Data Project (ACLED), https:// www.acleddata.com/2019/o5/10/midterm-elections-in-the-philippines-powerconsolidation-at-its-finest/ (accessed on 21 April 2020).

Klar, R (2019) Trump: US ready to 'wage war' on drug cartel 'monsters', The Hill, 11 May, https://thehill.com/homenews/administration/468977-trump-us-ready-to-helpin-cleaning-out-the-monsters-who-killed (accessed on 21 April 2020).

Médard, J.-F. (199o) 'L'Etat patrimonialisé', Politique Africaine, 39, pp. 25-36.

Morris, S. (2012) 'Corruption, Drug Trafficking, and Violence in Mexico', The Brown Journal of World Affairs, 18(2), p. 29.

Nadelmann, E.A. (1998) 'Commonsense Drug Policy', Foreign Affairs, 77(1), pp. 111-126.

Olukoshi, A.O. (2013) Drug Trafficking and its Impact on Governance in West Africa, WACD Background Paper 3 (Accra: West Africa Commission on Drugs), https://www. globalcommissionondrugs.org/wp-content/uploads/2017/o2/Drug-Traffickingand-its-impact-on-Governance-in-West-Africa-Final-Version-2013-o6-24.pdf (accessed on 21 April 2020).

Schwartlender, B., J. Stover, T. Hallett, R. Atun, C. Avila, E. Gouws et al. (2011) 'Towards an improved investment approach for an effective response to HIV/AIDS', Lancet, 377(9782), pp. 2031-41.

Stoler, A.L. (2018) 'The Politics of "Gut Feelings": On Sentiment in Governance and the Law', KNOW: A Journal on the Formation of Knowledge, 2(2), pp. 207-228.

The Daily Star (2019) 'Rights Situation in 2018: 'Extremely alarming”. The Daily Star, 11 January, https://www.thedailystar.net/country/highest-ever-extrajudicial-killingsin-bangladesh-in-2018-ask-1685563 (accessed on 21 April 2020).

Tinasti, K. (2019) 'Towards the End of the Global War on Drugs', Brown Journal of World Affairs, 25(2), pp. 109-120.

Transform Drug Policy Foundation (no date) The war on drugs: Wasting billions and undermining economies, Count the Costs Briefings (Bristol: Transform Drug Policy Foundation) https://transformdrugs.org/wp-content/uploads/2018/10/CTC-Economicsbriefing.pdf (accessed on 21 April 2020).

UnODC (United Nations Office on Drugs and Crime) (2017) World Drug Report 2017 (Vienna: UNODC).

UNODC (2013) The International Drug Control Conventions (Vienna: UNODC).

UNODC (2008) World Drug Report 2008 (Vienna: UNODC).

WACD (West African Commission on Drugs) (2014), Not Just in Transit: Drugs, the State and Society in West Africa (Accra: WACD).

Weber, M. (2003 [1921]) Economie et Société, Tome 1, les catégories de la sociologie (Paris: Agora Pocket). 